\title{
DIMENSIONS OF GANG ISSUES AT THE NATIONAL AND INTERNATIONAL LEVEL
}

\author{
Veronika SVATOŠOVÀ \\ Faculty of Regional Development and International Studies, Mendel University in Brno, Czech Republic \\ Josef SMOLÍK \\ Faculty of Regional Development and International Studies, Mendel University in Brno, Czech Republic \\ (C) 2016 Veronika SVATOŠOVÀ, Josef SMOLÍK \\ This is an open access article distributed under the Creative Commons Attribution-NonCommercial-NoDerivs license \\ (http://creativecommons.org/licenses/by-nc-nd/3.0/) \\ DOI: $10.1515 /$ eras-2016-0003
}

\begin{abstract}
The main objective of this paper is to define the main dimensions of gang, its structure, mutual connections and influence on the contemporary society at national and international level. This paper is based on knowledge about the issues of gang and presents the main differences and characteristics of formalized and non-formalized gang and the main identical and different characters. It comes from a study of current knowledge on the issue of gang and discusses its general forms. In this paper, a discussion of existing studies and typologies of these peculiar social groups, including an explanation is provided. The next section will introduce the particular qualities of the crimes committed by (mostly youth) gangs and explain their possible causes. The main findings of the paper is putting relations between formalized and non-formalized gang and their influence on the present and future society in the social, psychological, economic, ethnic and criminal dimension.
\end{abstract}

Keywords: gangs, organized crime, formalized gangs, non-formalized gangs, youth gangs.

\section{Introduction}

The term itself today is taken to mean a delinquent group or a criminal group. According to the OED, it derives from an Old English word, which meant 'Action or mode of going; way, passage' (Rejzek,2001).Weerman et al. (2009,p. 20 In Moravcová, 2012) defines a gang as any stable group of young people who spend their free time in public places and their illegal activities are an integral part of group identity. Klein et al. (2001) draws attention to the fact that gangs existing in Europe are with its characteristics very similar to American gangs. The authors talk about the so-called Eurogang paradox when we deny presence of gangs in Europe, because here we do not find gangs similar to those of the US, which are characterized by high levels of delinquency and organization. Otherwise, the authors recall the most mentioned American gangs do not have those characteristics. Eurogang researchers define a street gang as any durable street-oriented youth group whose involvement in illegal activity is part of its group identity (Haymoz, Maxson, Killias, 2014).A sociological definition states that a gang is 'an informal group comprised of individuals who undertake joint - mostly illegal - action' (Jandourek, 2007, p.90). A psychological definition denotes gang as characterising a certain formation; i.e. a grouping featuring a common identity, and the term 'gang' is most often used with the modifier 'criminal', thus linking it with the committal of offences (Hartl and Hartlová, 2010).

Another definition considers the gang to be a stable deviant or criminal group, mostly comprising youths, which is characterised by a division of roles between its individual members, with delinquent activities limited both spatially and temporally. In these structures, daily interactions between individuals are fundamental. Their roles are interconnected and 
complementary, giving rise to a collective consciousness of 'us' - the group identity. The group identity is manifest not only in the members' sense of belonging and inclusion in the group, but also as an interactively created notion of the shared fundamental distinguishing traits of the group, as held by its members (Heřmanová and Patočka, 2007, p.98).

Hrčka (2001, p. 146) defined gangs as small groups of professional or career deviants, organised for the purpose of achieving specific goals. Their deviation demanded activities coordinated by individuals, fulfilling specialised roles, wherein a division of labour takes place. At least some of these roles require special capabilities acquired during long-term training and practice. The gang often uses a special language (slang) and is based on a system of mutual obligations between its members. Deviant activities are planned in consideration of potential for success, prevention of exposure, and the neutralisation of society's system of control. Gang members may have links with certain individuals outside the gang (who might, for instance, sell stolen goods and provide gang members with various services, information and the means necessary for the deviant behaviour), as well as stable contacts and relations allowing them to coordinate their deviant activities and quickly disseminate the required information. A deviant gang can thus operate in a highly efficient manner with comparatively low risk, and the deviant career of its members is usually long-term and stable.

"Violence has often been a key attribute applied to gangs to distinguish them from other types of youth groups. However, the inclusion of violence in defining gangs has been disputed by those who suggest that gang involvement in violence needs to be assessed, rather than presumed“(Hazen 2011, p.372).

Haymoz states $(2010$, p. 12$)$ that nowadays there are many definitions of gang and it is clear the preference of one definition from others has resulted in obtaining completely different results under the different researches of delinquency. While one group of experts is still looking for one universal definition of a gang that would allow its exploration across continents and cultures, others warn that such a definition is not possible to find (Moravcová,2012). Petersen (2000, p.147) believes that one universal definition of gang will never be due to the fact that gangs are different in every society and every person has a different view on this definition. The theoretical definition of gang sounds quite clearly, but self-reporting study (ISRD-2 in 2007. In: Moravcová, 2010) implemented in selected EU countries talks about the fact that in practice it is difficult to understand the significance of gang. Especially in the case where the respondent is a member of a group and is not able to declare whether its interest group may be called a gang, and whether this group is committing delinquent behaviour. "Every individual can understand the lawlessness quite differently while not every illegal act is crucial to identify the respondent as a gang member. For example, drinking alcohol, which nowadays is also popular among adolescent individuals, but that is illegal, but not decisive in relation to the gang"(Moravcová 2009, p. 47-48). By this research, Youth gang can be indicated as a group that exists more than three months, whose members spend a lot of time in public places, are delinquent (at least two offenses of the same or different nature over the past year) and are considered as gang (Gatti and Haymoz, 2010). Detailed analysis to determine a level of delinquency in individual states is examined further (Gatti, Hatti, Schadee, 2011).

Pitts (2008) defined the different definitions of delinquent groups to the definition of a street gang (i.e. peer group, gang, organised criminal group, youth movements, young groups, criminal groups, wannable groups, street gangs, criminal business organizations). A gang can be considered in terms of: 1) the individual (the impact of gang membership on an individual), 2) small social groups (the gang itself, its norms, values, slang, etc.), 3) the majority culture, which opposes the gangs, ethnic or otherwise. Katz, Webb and Armstrong (2003) understand the term gang at the level of fear of the gang that can support individual 
status and tendency to victimization and delinquency.

\section{Features of formalized and non-formalized gangs}

Gangs are fairly generic term for a group with different interests. From this perspective, the authors distinguish formalized gangs and non-formalized gangs.

Formalized gangs have been the formalized structure, fixed system of values and rules and are mostly built on many years of history. The most common illegal activities of this gang belong the car theft, prostitution, illegal migration, trafficking the stolen goods, tax fraud, extortion and racketeering, setting up fictitious companies, illegal debt collection, bank fraud and money laundering, murders and other violent activities, corruption and other (Cejp et al. 2004, p. 37-38). Formalized gangs have moved to a higher level of organized illegal activities, i.e. the organized crime covered by legal business (money laundering, crime with international ramifications). Formalized gang is thus characterized as an organized criminal group, whose main objective is to maximize profits from illegal activities. Organized crime is defined as a systematic and planned crime committed by hierarchically structured group of persons, among whom there is a distribution of functions (Novotný et al., 2008). Baird (2012) conducted the research among gang members (in the UK), and concluded that masculinity plays a vital role in the cohesion and strength of the gang and a prerequisite for the effectiveness of organized crime. The contemporary trends of organised crime show the changing scale and nature of gang networks.' Specifically, there is concern that increased transnational interconnectivity may lead to national problems of violence and conflict spilling over into other (western) nations, or indeed that a range of once-local gangs are increasingly involved in criminal networks that link them far beyond the neighbourhood' (see Winton, 2014). It can be stated that gangs are found all over the world and today often respond to the changing spaces of globalizing cities (Winton, 2014).

Non-formalized gang is associated with a street gang (i.e. youth gang). Nonformalized gang is based on a sense of belonging, built a certain status, sense of security, and together sharing common values and interests. Youth gangs, which are the subject of this article, are generally associated with socially pathological phenomena and youth delinquency. It must be added that the creation of strong peer relationships, ranging from loose groups to precisely designated (named) youth gangs, is typical of periods of adolescence and young adulthood. It is worth noting at this point that the term 'gang' is mostly used in non-European contexts. In European literature, the terms 'troublesome youth groups' or juvenile delinquents are often preferred (see Kontos, Brotherton, 2008, p.113). Ruddel and Gottschall (2011) showed that not all groups that are labelled as gang pose the same security risk. These differences have been traced among youth gangs, prison gang and motorcycle gang. An important role is played by the diversity of the existence of these gangs and the age of its members. For this purpose, we consider a non-formalized as a youth gang.

Klein et al. (2001) highlights the activity of this type delinquent gang as one of its main characters, on the other hand, admits that committing illegal acts may not constitute the fundamental reason for their existence. We all know from everyday experience that adolescents and teenagers create peer groups, but there is no agreement as to where an ordinary peer group ends and a gang begins. Some authors uniformly associate gangs with delinquent and criminal behaviour, while others reject this. There is, however, a consensus in that the element of organisation is important, i.e. the planning of disorderly, delinquent or criminal behaviour (Hagedorn, 1998).

Non-formalized gang can be understood as an evolutionary precursor of formalized gang. Unlike the formalized gang, by a non-formalized gang, some of the features typical of 
organized crime - group hierarchy or division operations are missing (Novotný et al., 2008). Youth gangs are usually unorganized, do not intend the major gang leader, does not have a mutual loyalty and high cohesion. Researches focused on juvenile delinquent groups shows that there is often a change in the composition of the gang (Kuchta, Válková et al., 2012). Membership in such a group is highly variable, their existence is rather short. Non-formalized gangs are committing especially property crime, vandalism, graffiti, rioting, violence, bullying, and substance abuse. Procuring funds by petty theft can escalate into organized, planned actions (Decker, Curry, 2000). Boyce (2013) recognizes that risk factors for involvement in youth violence include: early childhood neglect and abuse, parental violence and drug addiction, school exclusion and early conduct disorders, violent victimization and repeated hospital visits. Street gangs (esp. in the USA) usually own their territories (streets and quarters of cities), where competition does not have access or it is not safe for them to visit the territory of other gangs (between gang activity also includes the fight for territory).

Studying of delinquency of youth groups may also bring new knowledge about the organized crime, which is a phenomenon of postmodern times. Organised crime is primarily dominates of adult offenders. Nevertheless, these offenders can recruit from delinquent groups and youth gangs. While girls usually leave the youth gangs gradually, as they grow up, the boys in the gang remain at an advanced age (Gatti, Haymoz, 2010). The results of the survey (see Scott, 2014) show that gang members tend to have stronger violent and aggressive attitudes compared to non-gang members, and length of institutional gang membership is statistically significant and negatively associated with violent and aggressive attitudes. Klein and Maxson (2006) identify six broad categories of variables that studies in many locations consistently found related to gang participation:

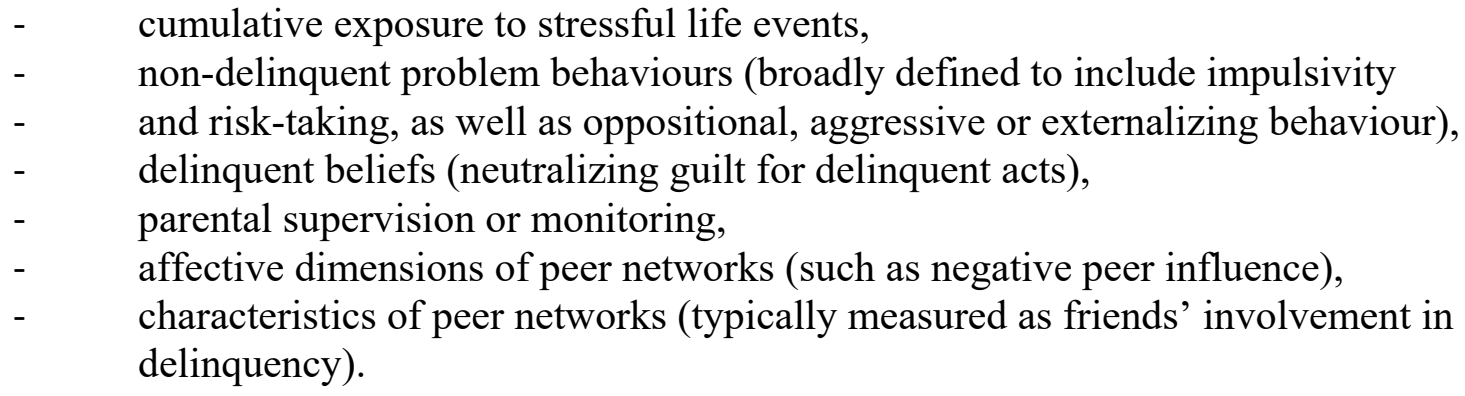

\section{The study of gangs, their values and norms}

Gangs are not exclusive to Western societies and have a longer history than is commonly thought. Historians indicate that named gangs were involved in criminal activities in seventeenth-century London; for example, the Mims, Hectors, Bugles and Dead Boys (see Spergel, 1990, p. 172). However, youth gangs are chiefly associated with the United States of America post-WWII, where they spontaneously appeared in great numbers (cf. Spergel, 1990).

Initial studies regarding these issues were undertaken by the Chicago School of Sociology, in which Frederic Thrasher played a pioneering role. The Chicago School focused on deviant individuals, the unsuccessful outsiders, the down-and-outers and the criminals. They studied them using biographical methods, employing labelling theory and gathering various characteristics of the individual subcultures or gangs (cf. Kontos and Brotherton, 2008, p. 257-261;Smolík, 2010, p. 61).

Another sociologist from the Chicago School, who also focused on the value systems of youth gangs, and emphasised similarities between the gangs and the culture they originated 
from, was Walter Miller. He argued that many of the values espoused by deviant groups were only repeating, albeit in a distorted or intensified manner, the 'focal concerns' of the adult working class population (cf. Kontos and Brotherton, 2008).

An important representative of the Chicago School in terms of gang studies was Albert Cohen. Drawing on earlier studies, Cohen developed a theory of delinquent subculture, which he presented in his 1955 monograph Delinquent Boys: The Culture of the Gang (cf. Smolík, 2010).Another important scholar investigating this topic was Lewis Yablonsky, who summarised his findings in the book The Violent Gang, describing more than a hundred youth gangs in New York (mainly in Manhattan's West Side). Yablonsky defined gangs (in his terminology a 'near-group') as a structure characterised by diffuse role definition, limited cohesion, impermanence, minimal consensus on norms, volatile and limited membership, and ambiguous leadership (Spergel, 1990;Hrčka, 2001).

Some gangs were engaged almost exclusively in seeking distraction and communality. Those gangs who fought often were divided into two main categories: defensive and fighting. Both types operated in clearly defined districts, usually over several city blocks. Within these districts, they claimed precedence among all adolescents, demanding respect. (Neighbouring gangs sometimes agreed on neutral territories such as churches, schools or - much more rarely - shops.) Young men from the gangs often had their own set of girls - the debutantes whom they defended from all other men. Sometimes the gang would seize other girls in order to rape them (Tilly, 2006, p. 103-104).

Some authors note that unique attributes characterised individual gangs; such as clothing, symbolism, colour codes, jewellery (typically golden chains), piercing, tattoos, gesticulation (for example hand signs), graffiti, attitudes to drugs, musical expression (for instance rap music) etc. According to Spergel (1990), gangs of youth tend to develop especially at times of radical social change and political instability. The issue of symbols and values gang slang spoken in detail Dowe (2011). Esbensen and Carson (2012) in his research of American street gangs to debunk some stereotypical perceptions about the composition and cohesion gang - on the basis of sex, race/ethnicity and immigrant status, age, delinquent activities. Changing trends and behaviour in society (e.g. due to emancipation) and changes the behaviour, motives and composition contemporary gangs.

\section{Dimensions of gangs}

A typical feature of formalized and non-formalized gangs is their coherence and synergy in the case of delinquent and illegal acts. Here the question arises, why these delinquent acts are committed. The concept of gang can be used in the social, psychological, economic, criminal or ethnic dimension. These dimensions are within the issue of gang intertwined and interdependent. The following text characterizes these dimensions (for formalized and non-formalized gang and identify the common features of these groups):

Social dimension. Members formalized and non-formalized gangs often come from the lower social strata, typical is a delinquent behaviour. According to Cohen (1955), the delinquency allows the individual to achieve an alternative status and allows him to carry out revenge on a system that has once and for all marked him as unsuccessful. The lower-class boys often associate into delinquent groups and gangs because they find themselves unable to adapt to an environment where they are evaluated according to middle-class standards, into which they have not been socialised, and which they therefore cannot meet. This situation usually arises in the school environment, where they face the standards of the middle classes. These include the will to succeed, orientation toward long-term goals, individual responsibility, rationality, sociality, verbal skills, patience and self-control. The lower-class 
boys then tend to become dependent on their peers, who satisfy their needs in terms of emotions and status, and whose standards and values then become a basis for their own behaviour. Yablonsky's study reported that many youths were unable to communicate with wider society, and that the problem of gang culture was not limited to large cities (Yablonsky 1962). Thrasher observed social and ecological areas in the city and argued that urban spaces influence the occurrence of criminal behaviour (for more details see Kontos, Broherton 2008, p. 258; Urban, Dubský, 2008, p. 364). Non-standard norms and values, and strange - often delinquent - forms of behaviour connected with such values, are then symptomatic of these territories, and are described by scholars as 'gangland' or 'delinquency areas' (Kuchta,Válková et al., 2005, p. 84).Alleyne and Wood (2011) examined the influence of social and environmental factors on the formation and development of the gang. The research showed that these factors strongly dominate over other factors and play a primary role in the formation and development of the gang phenomenon.

Criminal groups operate on a vast territory. This allows them not only to greater profits, but also reduces their risk. The existence and effect of formalized and non-formalized gangs is also a certain moral and social reflection of the entire society. In a society, where the basic moral and ethical values are diminished, patterns and natural authority with a certain moral status are missing; the influence of gangs is increasing, as well as their social implications for the entire society. It can also be noted that the organized crime and gang activities are successfully developing in the areas, where the legislation and public authority do not operate effectively (Cejp et al., 2004). The existence of gangs and the associated organized crime undermine the authority of state institutions, contribute to the economy of illegal practices and implant the pathologies to the lives of people (Cejp et al., 2004, p. 130). Gang plays irreplaceable role in the development of adolescent. It is the reference group, which surpasses the family. It offers a social space to create their own identity, social interaction, fulfils its function of separation from parents, especially when picking values, norms and attitudes of youth (Goldberg, 2003). Gang subculture is characterized by inconsistency with generally accepted values, their negation, opportunism, variability of gang activity, occurring vandalism, aggression or mutual loyalty among gang members (Munk, 2013). The influence of peers and the groups is considered to be the most important cause of juvenile delinquency men. Offenses committed in a group are characterized by a high relapse (Č́rtková, 2000).

Psychological dimension. Gang members often enter into groups based on frustration or impossibility of achieving their personal goals. Frustration, a logical consequence of such a handicap, is compensated for by creating groups of individuals who struggle with similar problems. In such groups, homogeneous normative systems arise through interactive processes. These systems differ substantially from the generally recognised rules of behaviour, justifying deviant forms of behaviour.

Gang member can compensate their desires and goals that are not in the majority group achieved. The degree of identification with a gang member is often absolute, achieves here a certain position which grants him the relevant personal satisfaction. At the same time, he encounters in gang with other individuals who share similar or the same interests, which increases the degree of gang cohesion. Gang provides to its members a certain degree of stability and some form of self-realization. An important factor for gang members are their friends, with whom the individual is identified. For example, Reiss (In: Večerka,2004) identifies three groups of criminogenic factors: defective or absent creation of internal control mechanisms in childhood, failure of the created internal control mechanisms, missing or conflicting social regulations of conduct (family, school, peers). Hirschi and Gottfredson (1990) developed this theory and highlight the particular focus on its own internal self- 
control. Low self-control ability is a mistake in the process of integration into society and is a significant predictor of criminal behaviour. According to them, delinquent persons are often those, whose low level of self-discipline is the result of inadequate socialization, whether in the family or at school.

Economic dimension. Gang members often come from social groups that are facing the problem of poverty, long-term unemployment, the threat of homelessness, lack of education and limited access to resources, increased crime and social exclusion. The discrepancy between what society declares concerning equal access and the possibilities open to all its members, and what the members of the unpropertied classes are fundamentally lacking (e.g. access to education, money, an upbringing emphasising a honest and upright life, and other prerequisites), is then compensated for in the environment of the delinquent gang. Here boys obtain a status denied to them elsewhere, here they are recognised and understood; and if they fulfil certain conditions, they gradually climb up the group hierarchy. Moreover, they can take revenge on society for what they perceive as the wrongs committed against them. The existence of gangs has a negative economic impact on the society. The strength of gangs grows during unstable economic and social environment that encourage delinquent and criminal behaviour. Cejp et al. (2004: 20) declares that the concept of organized crime can be traced as activities developed on a rational economic basis and functioning as a complement to the market that meets the public's demand for illegal goods and services. Many signs of organized crime are therefore fundamentally identical to the characters of legal businesses. Organized crime may be developed as a supplement to a functioning market focused on the provision of goods and services in the illegal sector of demand, but also in terms of an incorrect market, suppression of normal market relations and the informal economy as substitutes of market, distributing legal goods and services, but hardly available.

Some gang activity has been associated with economic crime (especially money laundering activity, international economic transfers and offshore registration, especially in connection with tax evasion, corruption). Ministry of Finance of the Czech Republic estimated the average annual return of economic crime CZK 170- 180 billion, of which CZK 80 - 90 billion a year are "washed" (Cejp et al., 2010). The legalized proceeds of crime in economic development are considered as a disequilibrium factor whose destabilizing effects can be very serious. Organised crime has a surplus of funds; in legal economic structures, these funds are missing. Regarding sales, the economy differs criminal organizations that either based on need, which is largely pathological (drugs, prostitution, gambling), on necessity (usury), or from destitution (smuggling). (Cejp et al., 2004, p. 136)

Criminal dimension. New entrants to the non-formalized gang may be prone to delinquent and criminal behaviour and gang enable to fully implement these tendencies, or a gang member can learn this behaviour in order to obtain recognition, respecting certain rules and standards of the gang, achieving the objectives of gang or fear of exclusion of the gang. Formalized gangs are based on the commission of organized crime. These gangs have a very sophisticated structure and hierarchy in the organization of the offenses. Practice shows that these gangs are involved in the overall crime in up to $80 \%$. The strong connections, history and coherence with the legal business environment and political scene indicate that criminal aspect of gangs is one of the most important factors that distort the contemporary society. A typical characteristic of organized crime is the fact that due to the finalization of the offense, the entire of crime string is committed (organized sequence of crime and accompanying events). Organised crime is dangerous, because it penetrates the political and economic structures, assimilates in the society and is characterized by a high latency (Sikora, 2008).

Non-formalized gangs are usually tied to a specific environment or location and have a lower degree of organization and hierarchy; they are characterized by a lower degree of 
stability. Motive of achieving the constant high profit is not in primary; on the contrary, the motive of authority or dominance in a particular environment coupled with of internal solidarity may predominate. Especially in the street gangs, the value may be the belonging to a gang itself, which is associated with a relatively gang hallmark, namely that allegiance to a particular gang is in the environment publicly acknowledged, often through the various symbols directly manifested, unlike strict conspiracy of organized crime. Criminal activities developed on the principle of supply and demand may exist, e.g. when gang is involved into the drug or arms trafficking, but rather exist as one of the activities as well as more dealership than the "large business". This crime is less sophisticated, less conspirative and qualified, with a greater tendency to direct negotiations with the use of violence, than is the case of organized crime. Accompanying (cover and security) activities, including corruption are not characteristic for gang activity; gang conflict contrary to public authorities is open. However, the organized crime may use non-formalized gangs for their own purposes and the performance of certain activities (dealers, violent actions, etc.). Non-formalized gangs might be described as simpler forms of development, possibly one of the sources of organized crime (Kenney and Finckenauer, 1995).

Ethnic dimension.Gang members come together for a specific interest. One of these reasons may be relevant for ethnic group that implements a particular target expressing the interests of that ethnic group. This ethnic group is considered as a minority that is fighting to achieve the interests and needs of ethnicity. Eric Schneider undertook a detailed study of the evolution of gangs in New York City between 1940 and 1975. He showed that post-war gangs established themselves along racial and ethnic lines, broadly corresponding to the racial and ethnic segregation in the city. Gangs sought to accumulate opportunities and operated within limited networks, jealously guarding the resources from which members benefitted. For many participants the primary advantages were protection and self-respect. For their leaders, gangs sometimes also introduced benefits in terms of payment and political power. Minority groups of population are traditionally seen as the originator of crimes. In connection with this fact, the term ethnic or immigrant gang began to be used (the ethnic aspect is typical for American street gangs among African-Americans, resp. Hispanics). As Fiala et al. (2003) stated ethnic gang are characterized mainly by the fact that it is largely made up of members of a particular ethnic group. Form of crime in part reflects nationality and origin of a minority. Now ethnic factor plays an important role in the sense that criminal organizations were created on the single ethnic ground. After expanding the number of members, activities and ethnic homogeneity, it retains the core or the structure of the organization. This element provides to organizations many advantages such as ease of communication, trust, cohesion, conspiracy, etc. (Schneinost et al., 1997).

In the context of the Czech debate about youth gangs, Romani groups then began to be discussed. They often appear to have the character of a gang and ethnic belonging can be understood as an element creating gang cohesion. Here we can distinguish the two levels on which the values (and norms, attitudes, customs, stereotypes) of the gang and the majority society differ. The first level concerns the discrepancy in norms between the gang and majority society; the second the relationship between the majority society and ethnic groups. In these processes, a sense of ethnic awareness and belonging is important. When studying ethnic gangs, we might consider entirely specific cultural patterns that pertain to, for instance, manifestation of violence, emotionality, legal and moral awareness, etc. An ethnic gang must be perceived through the prism of socialisation. This means that the gang serves an important function in the socialisation of an individual. The cultural patterns of a gang are then imitated, enlarged and shifted. Gangs' value systems are confronted with those of the majority society, and this confrontation can manifest in violence and delinquent behaviour. 
The following Table 1 summarizes the characteristics of a formalized and nonformalized gang in the social, psychological, economic, ethnic and criminal dimension. The table also demonstrates the mutual and different features of formalized and non-formalized gang according to each dimension.

\begin{tabular}{|c|c|c|}
\hline $\begin{array}{r}\text { Dimensions } \\
\text { of gangs }\end{array}$ & $\begin{array}{r}\text { Type of } \\
\text { gang }\end{array}$ & $\begin{array}{c}\text { Features of } \\
\text { formalized and non-formalized gangs }\end{array}$ \\
\hline \multirow{2}{*}{$\begin{array}{r}\text { Social } \\
\text { dimension }\end{array}$} & $\begin{array}{r}\text { Non- } \\
\text { formalized gang }\end{array}$ & $\begin{array}{l}\text { - Gang members often come from lower and } \\
\text { lowest social strata (from problematic families) } \\
\text { - Exclusion from the majority group or the } \\
\text { impossibility to incorporate to it } \\
\text { - The aim of these gangs is to differentiate } \\
\text { from the majority society - creating own symbols, values, } \\
\text { norms and practices } \\
\text { - The rate of a gang formation is a reflection } \\
\text { of moral and ethical values in society (lack of moral authority, } \\
\text { moral and ethical aspect of the majority society at a low level, } \\
\text { etc.). } \\
\text { desire to achieve a certain social status, which is not able to } \\
\text { achieve in the majority group } \\
\text { - Gang is the reference group and often } \\
\text { surpasses the family }\end{array}$ \\
\hline & $\begin{array}{r}\text { Formaliz } \\
e d \\
\text { gang }\end{array}$ & $\begin{array}{l}- \text { Gang members often come from lower and } \\
\text { lowest social strata } \\
-\quad \text { Formalized gang often infiltrated among the } \\
\text { majority society - some manifestations of criminal behaviour } \\
\text { (e.g. corruption) are accepted by the majority society (lower } \\
\text { moral and ethical status of the majority group) } \\
-\quad \text { The significance of formalized gangs is } \\
\text { increasing in societies where legislation and public authority } \\
\text { do not operate effectively } \\
-\quad \text { Organized crime undermines the authority } \\
\text { of state institutions, brings to the economy illegal practices, } \\
\text { implants the pathologies to the lives of people } \\
-\quad \text { In a global world, transnational organized } \\
\text { crime threatens all mankind }\end{array}$ \\
\hline \multirow[t]{2}{*}{$\begin{array}{r}\text { Psychologic } \\
\text { al dimension }\end{array}$} & $\begin{array}{r}\text { Non- } \\
\text { formalized } \\
\text { gang }\end{array}$ & $\begin{array}{l}\text { Gang membership is an expression of } \\
\text { frustration and deprivation in the majority society (as a } \\
\text { member of the ethnic groups, socially excluded groups, or } \\
\text { expressing the inability to achieve personal goals within the } \\
\text { majority group) } \\
-\quad \text { Gang members often come from troubled } \\
\text { family environment } \\
\quad-\quad \text { Unsolved question, whether membership in } \\
\text { the gang leads to delinquency, or individuals prone to } \\
\text { delinquent behaviour are grouped into gang } \\
\quad-\quad \text { Low self-control ability is a mistake in the } \\
\text { process of integration into society }\end{array}$ \\
\hline & $\begin{array}{r}\text { Formaliz } \\
\text { ed }\end{array}$ & Often the recruitment of non-formalized \\
\hline
\end{tabular}




\begin{tabular}{|c|c|c|}
\hline & gang & $\begin{array}{l}\text { gang (relapse of criminal activity, the individual cannot } \\
\text { enforce in society, in another way) } \\
\text { - The occurrence of pathological phenomena } \\
\text { of group members (alcoholism, relapse crimes, prone to } \\
\text { violence, problematic relationships with the primary and } \\
\text { reference groups, etc.). } \\
\text { - Obtaining a sense of security, the possibility } \\
\text { of alternative self-realization (which was in the majority group } \\
\text { almost impossible) } \\
\quad \text { Obtaining a sense of belonging, } \\
\text { compensation trauma and unmet goals of childhood } \\
\quad-\quad \text { Compensation of internal conflicts, low self- } \\
\text { esteem, other manifestations of disturbed psyche, membership } \\
\text { in some forms could be a manifestation of a certain } \\
\text { personality disorders }\end{array}$ \\
\hline $\begin{array}{r}\text { Economic } \\
\text { dimension }\end{array}$ & $\begin{array}{r}\text { Non- } \\
\text { formalized gang }\end{array}$ & $\begin{array}{l}\text { - Most gang members come from low social } \\
\text { strata, which meet less education, high long-term } \\
\text { unemployment, pathological behaviours, high personal debt, } \\
\text { etc. } \\
\text { norm for individuals (patterns within the family, as well as } \\
\text { with other reference groups) } \\
\text { - Economic consequences of non- formalized } \\
\text { gangs are primarily evident (apply only to petty crime, which } \\
\text { do not seriously harm the economy); the social aspect of gang } \\
\text { is more important (members of formalized gang often recruit } \\
\text { from non-formalized gang - in this form, we can consider the } \\
\text { economic dimension of the gang) }\end{array}$ \\
\hline & $\begin{array}{r}\text { Formaliz } \\
e d \\
\text { gang }\end{array}$ & $\begin{array}{l}\text { - Associated with economic crime, which is } \\
\text { reflected in the effect of the informal economy and thus } \\
\text { reduces the overall performance of the country } \\
\text { - Activities developed on a rational economic } \\
\text { basis and functioning as a complement to the market that } \\
\text { meets the public's demand for illegal goods and services } \\
\text { - Often connections with the legal business } \\
\text { environment and political scene } \\
\text { - Organized crime has a surplus of funds in } \\
\text { legal, in economic structures these funds are missing } \\
\text { - Activities of economic crime damage the } \\
\text { national and global economy }\end{array}$ \\
\hline $\begin{array}{r}\text { Criminal } \\
\text { dimension }\end{array}$ & $\begin{array}{r}\text { Non- } \\
\text { formalized gang }\end{array}$ & 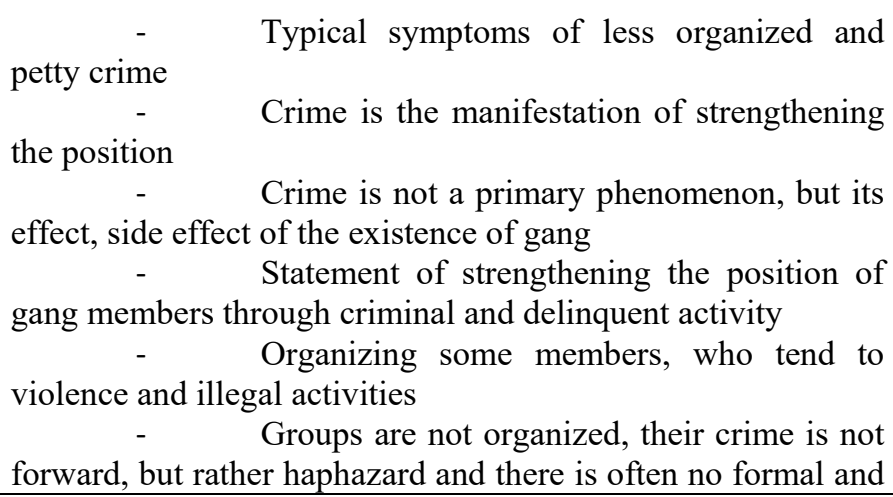 \\
\hline
\end{tabular}




\begin{tabular}{|c|c|c|}
\hline & & $\begin{array}{l}\text { informal leader } \\
-\quad \text { Committing the high-risk crimes, whose } \\
\text { profitability is low } \\
-\quad \text { Simpler forms of formalized gangs, possibly } \\
\text { one of the sources of organized crime }\end{array}$ \\
\hline & $\begin{array}{r}\text { Formaliz } \\
e d \\
\text { gang }\end{array}$ & $\begin{array}{l}\text { Typical manifestations of organized crime } \\
\text { groups or economic crime } \\
-\quad \text { The crime is the primary objective and } \\
\text { phenomenon; the main goal of organized crime groups is } \\
\text { profit } \\
\text { - Illegal and criminal activities of the group } \\
\text { are a manifestation of the informal economy and their activity } \\
\text { is the result of meeting supply and demand for illegal markets } \\
-\quad \text { They have a very sophisticated structure and } \\
\text { hierarchy in the organization of the offenses } \\
-\quad \text { Gangs are involved in total criminal } \\
\text { activities up to } 80 \%\end{array}$ \\
\hline \multirow{2}{*}{$\begin{array}{r}\text { Ethnic } \\
\text { dimension }\end{array}$} & $\begin{array}{r}\text { Non- } \\
\text { formalised gang }\end{array}$ & $\begin{array}{l}\text { - The feeling of belonging to a particular } \\
\text { ethnic group } \\
-\quad \text { Members of an ethnic group shares a sense } \\
\text { of security and mutual cultural values and norms } \\
-\quad \text { Members of the ethnic group feel to be } \\
\text { socially excluded objectively (language barrier, different } \\
\text { customs and values of the majority society) and subjectively } \\
\text { (feeling of rejection of the majority group - racism, } \\
\text { xenophobia, etc.) } \\
-\quad \text { The emergence of non-formalized gang as } \\
\text { defiance of the majority group, which has often criminal and } \\
\text { delinquent subtext } \\
\quad-\quad \text { The ethnic motive is the main form of street } \\
\text { gangs (esp. in the US African-American or Hispanic gangs, in } \\
\text { the CR the Roma community) }\end{array}$ \\
\hline & $\begin{array}{r}\text { Formaliz } \\
\text { ed } \\
\text { gang }\end{array}$ & 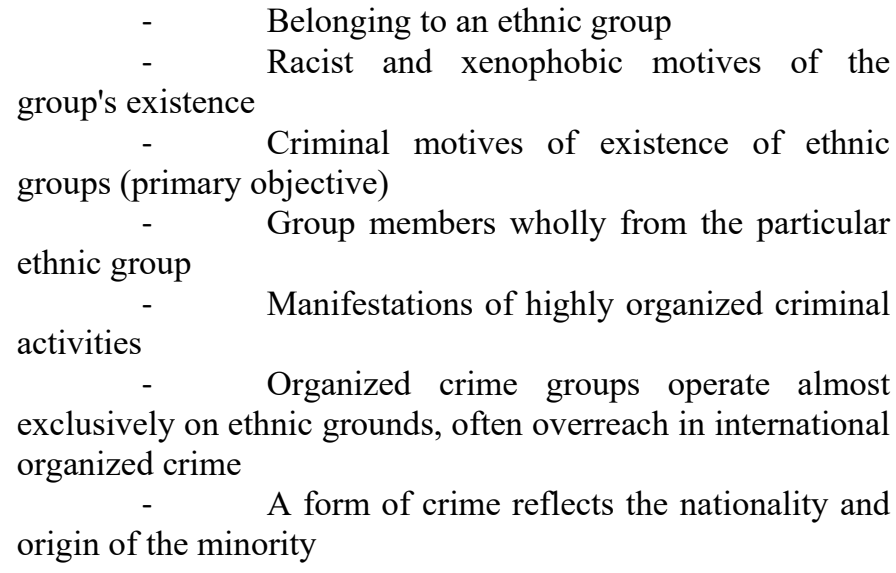 \\
\hline
\end{tabular}

Table 1.Dimensions of formalized and non-formalized gangs 


\section{Discussion}

The history of gangs and their activities have an economic, social and psychological impact on the majority society. Therefore, the question is: whether this impact could be economically evaluated. Due to the fact that gangs are characterized by illegal activities, it is difficult and practically impossible to make any relevant statistics. One of the main problems of the validity of the official statistics is their lack of ability to measure all forms of crime that exists. We can find only those illegal acts that were in some way identified and recorded by the police and we are talking about frequently recorded crime (Novotný et al., 2004). The result is what we call "black number" in the practice, i.e. hidden or latent criminality (Moravcová, 2012b).

Because of the problems associated with official statistics in the mid-20th century, researchers have begun to address other ways of measuring crime, which would allow compensating for such shortcomings, such as the already mentioned "black number". The most widely used indicator that solves the problems of official statistics is called selfreporting studies (Moravcová, 2012b, p. 22). They, unlike the official statistics, contain the detailed information about the perpetrators, which allows us to proceed a deeper analysis of delinquency (its context and circumstances) and empirical testing of theories, most of which focus on children and youths (Podaná, 2011, p.43;Tomášek, 2013). They allow capturing those forms of behaviour that are not generally considered as criminal offenses, e.g. alcohol, soft drugs, truancy, but correlate to the delinquent behaviour (Podaná, Buriánek, 2008). The findings of criminal or otherwise problematic behaviour in this age group are very valuable because they can be derived from appropriate preventive or other measures, where effectiveness of the youth is higher than for adult offenders (Tomášek, 2013).

Issues, which arise in relation to juvenile delinquency within the gang, are the relationship between a group of juveniles and delinquent activities. There is a question, whether the membership in a gang, resp. spending time with delinquent persons leads to the crime, or vice versa, whether the behaviour of juvenile delinquent leads to familiarization with other offenders (Pošíková, 2014). For example, Reckless (In: Pošíková, 2014) considers the influence of peers as one of the most important factors of etiology of juvenile delinquency. Youth takes the values, attitudes and behaviour from their peers and also becomes delinquent. On the contrary, according to Sheldon and Eleanor Glueck, gang membership cannot be the cause of delinquency, because most of the boys become delinquent before they enter into a gang. Edwin Sutherland emphasizes the role of the so-called intimate groups, i.e. family or peers, with whom the individual is in frequent contact and who have shaped his world view. He considers that the deviant behaviour is essentially culturally transmitted, more precisely, that an individual learns to generally accept the rules of interaction within small social groups (Munk, 2001). This criminological question therefore remains unsolved (Hirschi, 2009; Pošíková, 2014).

The most crucial findings in the developmental criminology, in the issue of formalized and non-formalized gangs, can be summarized in the following points (Tomášek, 2013; Pošíková, 2014; see also Matoušek, Matoušková, 2011):

The age, at which delinquent behaviour occurs, is the period between eight to fourteen years of age. End of criminal career is then in the majority of offenders seen in the age group 20-29, but a small part of them continues in the crime.

Prevalence of criminal behaviour reaches its peak in late adolescence - roughly between the fifteenth and nineteenth year of life. 
- The sooner an individual commits an offense, the more likely it is for him a relatively long criminal career, as well as committing more offenses.

In criminal behaviour, in terms of the transition of individuals from childhood to adolescence, and from adolescence into adulthood, some continuity exists, i.e. people, who commit a large number of offenses during one phase of life, have a significant risk that the same trend is also reflected in the following stage.

A small group of offenders (i.e., chronic offenders) is responsible for a substantial proportion of all crimes per population. For these individuals, the young age is symptomatic when committing the first offense, a high frequency in the commission of crimes and a long criminal career.

The transition to adulthood is associated with changing motives. For juvenile offenders, there is also a rich variety - desire for excitement and fun, efforts to fight off boredom or emotional reasons caused by the prospect of easy profits. In adulthood the principle of utilitarianism has been completely dominated.

Gang membership can affect criminal behaviour - it can increase the risk of involvement in serious and violent crime, and increase the frequency of serious and violent crime. The key question here is: what strategies can be employed to prevent the development of criminal or violent youth gangs and what forms of intervention are most appropriate to diminish gang-related activity? The answer is ambiguous. Some suggestions are used in the Australian study (more details see White, 2002). On the other hand, Hughes and Short (2006) describe the relation between the street gangs, its violence and proportion of relapse when returning back from prison back to the street and violent environment. The issue of gangs and violence and its prevention is still not clearly solved.

\section{Conclusion}

The organised crime groups (formal and non-formalized gangs) damage the public and private sector, to some extent, they can directly threaten the safety of citizens. This threat affects the whole globalized world. In the global social system, there are criminogenic elements that enable the formation and operation of transnational organized crime, which poses a danger to society.

The main contribution of this paper is summarizing the current knowledge on the issue of gang at national and international level, defining and determining the characteristics of a formalized and non-formalized gang and their connections in the social, psychological, economic, ethnic and criminal dimension. At the same time, it determines the possible definition of gang and its perception and meaning for the contemporary society.

This paper showed it is not possible to pursue the issue of formalized gangs, as well as non-formalized (youth) gangs separately. This phenomenon must be taken into account in the interaction (not as an isolated problem), i.e. the effect of non-formalized gangs on the rise and importance of formalized gangs. This paper showed that there is a close relationship between formalized and non-formal gang. 


\section{References}

Alleyne, E., Wood J.L. (2014). Gang Involvement: Social and Environmental Factors. Crime \& Delinquency.60(4), 547-568.

Baird, A. (2012). The violent gang and the construction of masculinity amongst socially excluded young men. Emerald Group Publishing Limited: Safer Communities. 11 (4), 179-190.

Boyce, J.C. (2013). Ending Gang and Youth Violence: A Critique. Youth Justice13(3), 193-206.

Cejp, M.et al. (2004). Organizovaný zločin v České republice. Praha: Institut pro kriminologii a sociální prevenci.

Cejp, M et al. (2010). Vývoj organizovaného zločinu na územi České republiky. Praha: Institut pro kriminologii a sociální prevenci.

Č́rtková, L. (2000). Policejni psychologie. Praha: Portál.

Cohen, A.K. (1955). Delinquent boys: The Culture of the Gang. New York: Free Press.

Decker, S.H., Curry G.D. (2000). Addressing key feature sof gang membership. Measuring the involvement of young members. Journal of Criminal Justice, 28.

Dowe, D. (2011). Gangs: Slang, Words, Symbols. Law \& Order59(3), 48-52.

Esbensen F., Carson D.C. (2012). Who Are the Gangsters?: An Examination of the Age, Race/Ethnicity, Sex, and Immigration Status of Self- Reported Gang Members in a Seven-City Study of American Youth. Journal of Contemporary Criminal Justice 28(4), 465-481.

Fiala, P. et al. (2003). Organizace etnických menšin a prosazování jejích zájmů. In Sborník prací Fakulty sociálních studii Brněnské university Sociální studia 9, Brno:Masarykova univerzita, URL (consulted 18 August 2015): http:// http://socstudia.fss.muni.cz/dokumenty/080305095650.pdf

Gatti, U., Haymoz, S., Schadee H.M.A. (2011). Deviant Youth Groups in 30 Countries: Results from the Second International Self-Report Delinquency Study. International Criminal Justice Review, 21(3),208-224.

Gatti, U., Haymoz S. (2010). Girl Members of Deviant Youth Groups, Offending Behaviour and Victimisation: Results from the ISRD2 in Italy and Switzerland, European Journal on Criminal Policy and Research, $16(3)$.

Golberg, B.U. (2003).Freizeit und Kriminalität bei Jugendlichen. Zu den Zusamenhängenzwischen Freizeitverhalten und Kriminalität. Baden: Nomos Verlagsgesellschaft Baden.

Hagedorn, J.M. (2008). A World of Gangs. Armed Young Men and Gangsta Culture. Mineapolis: University of Minnesota.

Hagedorn, J. (1998). Discussion of Gang Definition. Crime \& Justice: A Review of Research24,366-368.

Hart, P., Hartlová, H. (2010). Velký psychologický slovník. Praha: Portál.

Haymoz, S., Maxson, Ch., Killias, A. (2014). Street gang participation in Europe: A comparison of correlates, European Journal of Criminology 11(6).659-681.

Haymoz, S. (2010). Les gangs en Suisse: délinquance, victimization et facteurs de risque. Lausanne: Université de Lausanne.

Hazen, J.M. (2010). Understanding GandsAs Armed Groups. Internetional Review of the Red Cross 98(878): 369-386.

Heřmanová, E., Patočka,J. (2007).Regionálnísociologie, sociologie prostoru a prostředi II. Praha: VŠE.

Hirschi, T., Gottfredson, M.R. (1990). A General Theory of Crime. California: Stanford University Press.

Hirschi, T. (2009). Causes of delinquency: with a new introduction by the author. New Brunswick: Transaction Publishers.

Hrčka, M. (2001). Sociální deviace. Praha: Sociologické nakladatelství.

Hughes, L.A., Short J.F. (2006). Youth Gangs and Unions: Civil and Criminal Remedies. Trends in Organized Crime, 9(4), 43-59.

Jandourek, J. (2007). Sociologický slovník. Praha: Portál, 2nd ed.

Katz, Ch.M. et al. (2003). Fear of Gangs: A Test of Alternative Theoretical Models. Justice Quarterly,20 (1), 95-130.

Kenney, D.J., Finckenauer, J.O. (1995) Organized Crime in America. Wadsworth, Belmont, California.

Klein, M. W., Maxson, C.L. (2006). Street Gang Patterns and Policies. New York: Oxford University Press.

Klein, M.W. et al. (2001). The Eurogang Paradox. Netherlands: Kluwer Academic Publishers.

Kontos, L. Brotherton D.C. (2008). Encyclopedia of Gangs. Westport: Greenwood Press.

Kuchta, J, Válková, H. et al. (2005). Základykriminologie a trestnípolitiky. Praha: C. H. Beck.

Kuchta, J., Válková, H.et al. (2012). Základy kriminologie a trestnípolitiky. Praha: C. H. Beck.

Matušek, O., Matoušková, A. (2011). Mládež a delikvence. Praha: Portál.

Moravcová, E. (2009). Problematika part, gangů a delikventníchuskupenímládeže. Praha: Univerzita Karlova.

Moravcová, E. (2010). Gangyv mezinárodnímsrovnání (PodleISRD-2). In Kdo slyši hlas volajícího na poušti: Referáty z konferenceve Vranověnad Dyjí. Praha: Masarykovačeskásociologickáspolečnost,65-75. 
Moravcová, E. (2012). Jakdefinovat a měritčlenství v gangu: Českárepublika v evropskémkontextu. Data a výzkum - SDA Info 2012. Praha: Sociologickýústav AV ČR, URL (consulted 18 August 2015): http://dav.soc.cas.cz/uploads/7429da3f1095190bc7e2e0bad2ea47f0a7d6bfc2_DaV12_2_p151171_Moravcova.pdf.

Moravcová, E. (2012b). Identifikace respondent ajakočle na gangu v ISRD-2: Česká republika v evropské $m$ kontextu. Praha: Univerzita Karlova v Praze,URL (consulted 18 August 2015): file://C:/Users/Veronika/Downloads/DPTX_2010_2_0_286864_0_112151.pdf

Novotný, O.J. et al. (2004). Kriminologie. Praha: ASPI Publishing.

Novotný, O.J. et al. (2008). Kriminologie. Praha: ASPI - Wolters Kluwer.

Pechová, E. (2007). Migrace z Vietnamu do české republiky $v$ context u problematiky obchodu $s$ lidmi a vykořistování. Praha: La Strada.

Petersen, R.D. (2000). Definition of a gang and impacts on public policy. Journal of Criminal Justice,139-149.

Pitts, J. (2008). Describing and defining gangs. Community Safety Journal,7(1), 26-32.

Podaná, Z., Buriánek J. (2008). Českámládež v perspektivě delikvence. Praha: FF UK.

Podaná, Z. (2011). Delikvence mládeže a rodina. Praha: Univerzita Karlova.

Pošíková, L. (2014). Vybrané aspekty criminality mládeže: Gangy a delikvent nískupin y mládeže. Praha: Univerzita Karlova. Available at: http://svoc.prf.cuni.cz/sources/7/12/391.pdf.

Rejzel, J. (2001). Český etymologický slovnik. Praha: LEDA.

Ruddell, R., Gottschal, A. (2011). Are All Gangs Equal Security Risks? An Investigation of Gang Type and Prison Misconduct. Southern Criminal Justice Association: Am J Crim Just, 36,265-279.

Scheinost, M. et al. (1997). Výzkumstruktury, forem a možností postihu organizované hozločinu v České republice. Praha: IKSP.

Scott, D.W. (2014). Attitude is everything: Youth attitudes, gang involvement, and length of institutional gang membership.Group, Processes \& Intergroup Relations, 17(6), 78 -798.

Sikora, J. (2008). Organizovanýzločin vČeské republice $z$ pohledu kriminologického. Praha: UniverzitaKarlova.URL (consulted 18 August 2015): http://is.muni.cz/th/108009/pravf m/Diplomka Organizovany zlocin je fenomen dnesni doby a to v.pdf.

Smolík, J. (2010). Subkulturymládeže. Uvedeni do problematiky. Praha: Grada Publishing.

Spergel, I.A. (1990). Youth Gang: Continuity and Change. Crime and Justice, 12, 171-275.

Tilly, Ch. (2006). Politikakolektivníhonásilí. Praha: Sociologickén akladatelství.

Tomášek, J. (2013). Self-resportové studie kriminálního chování. Praha: Institut pro kriminologii a sociálníprevenci.

Urban, L., Dubský, J. (2008). Sociálnídeviace.Plzeň: AlešČeněk.

Večerka, K. (2004). Mladiství pachatelé na prahutisíciletí. Praha: Institut pro kriminologii a sociálníprevenci.

Weerman, F. et al. (2009). Eurogang program manual.St. Louis, University of Missouri.

White, R. (2002). Understanding Youth Gangs. Australian Institute of Criminology: Trends and Issues, August $2002,1-6$.

Winton, A. (2014). Gangs in Global Perspective. Environment \& Urbanization 26(2): 401-416.

Yablonsky, L. (1962). The Violet Gang. New York: The Macmillan Company. 